\title{
Towards the greenship assessment and certificate of new building Design Recognition (DR) for the design of IDB-funded integrated classroom building Universitas Negeri Malang, Indonesia
}

\author{
Apif M. Hajji ${ }^{1, *}$ and Dian Ariestadi ${ }^{1}$ \\ ${ }^{1}$ Civil Engineering Department, Universitas Negeri Malang, 65145 Malang, Indonesia
}

\begin{abstract}
To foster Universitas Negeri Malang (UM) as the Center of Excellence in Learning Innovation, with the support from the Islamic Development Bank (IDB), two 9-storeys integrated classroom buildings will be built, having the total built area about $44,800 \mathrm{sqm}$, which are divided exactly in two rectangle-shaped towering blocks. The buildings are projected to have green building status for Design Recognition (DR) by approaching GBCI's greenship rating system. By using DED documents of the buildings, this study analyzes technical and engineering aspects to fulfill greenship requirements and recommends a specific level of greenship. The results show that overall targeted score is 47 and recommend Gold level of greenship.
\end{abstract}

\section{Introduction}

As part of the IDB-funded project for developing Universitas Negeri Malang (UM) as the Center of Excellence in Learning Innovation, two 9-storeys integrated classroom buildings will be built in a site of $3.8 \mathrm{Ha}$ located inside campus. The total built area are about 44,800 sqm, which are divided exactly in two rectangle-shaped towering blocks. These two buildings are functioned as classrooms, laboratories, seminar rooms, lecturer's cubical rooms, meeting rooms, and studios. As new building design, the Detailed Engineering Design (DED) documents are also directed to have green building components on its technical specifications. The green building achievement for these buildings will be approached by using the certificate of Greenship issued by Green Building Council Indonesia (GBCI). The Greenship from GBCI is based on the scores of a specific rating system, which are categorized as Design Recognition (DR) and broken-down from each related technical specifications of building design. This study investigates and analyzes components in DED document for fulfilling green requirements as stated on the rating system. The expected results of this study will be used as the recommended and targeted score of the DR for a specific Greenship level.

\footnotetext{
* Corresponding author: apif.miptahul.ft@um.ac.id
} 


\section{Related Studies}

Greenship certificate for green building design had been investigated from various perspectives. There is a study assessing criteria used and applied in sustainable rating systems in Indonesia, Malaysia, and Philippines [1]. These three countries with many other nationals joined the World Green Building Council (WGBC) to foster the continuous efforts on green building issues by replacing conventional existing method. In another perspective, energy performance of buildings is a very critical measure for energy efficiency and conservation plans [2]. Most rating systems for greenship refer to accomplishment of a set of requirements for certification, as well as deployment of sustainable materials and resources. From the contractors' point of view, selected procurement methods and finding sustainable resources may lead to different type of encounters, which could have impacts on scheduling and costing of green building projects. In this context, risks related to the use of sustainable materials and resources, particularly in green construction projects, are crucial to investigate [3], [4].

While the sustainability issues and concepts have gained acknowledgment in Indonesia, many contractors still have been deliberately implementing these concepts in their projects. An assessment model has been developed to observe contractors' preparedness, i.e. awareness, willingness, and capacity upon sustainability principles [5]. The model includes indicators obtained from both green building and green contractor approaches, and sustainable construction best practices. In response to sustainability concerns, the country like Indonesia, Malaysia, or other South Asian countries, are in various stages of implementation of green building, which include both internationaladopted systems and local-adjusted systems [6].

Other studies found that the implementation of Building Performance Assessment Systems (BPASs) have the potential to accelerate the succeed of sustainable construction. The use of BPASs in developing countries is conducted to establish a country-specific building sustainability assessment framework that takes relevant green issues into account [7]. In different point of view, there is also a study on the relationship between green building issues and inhabitants' perception on the greenship rating system [8]. The result showed that only half of inhabitants agreed on how the office building is within greenship rating system. The Indoor and outdoor comfort criteria must also be perceived on implementing green building design concept for office buildings or vertical housing [9]. Regarding the relationship between the concepts of green building on students' green behavior, a research shows that there is a significant relation between them [10]. The result proved that architecture can modify the user's behavior. An energy audit also is one technique to deal with the excessive use of energy in buildings [11]. Some previous research findings have shown that most electrical energy in buildings used for air conditioning (AC) system. Calculation of Overall Thermal Transfer Value (OTTV) has been proven the significance of performing since the early stage of the design of a building to achieve energy efficiency. Some studies have identified the obstacles in promoting green building issue in Indonesia from building inhabitants' perspective [12]. It was identified that the obstacles are mostly about supporting knowledge and environmental-thought atmosphere in management level, as well as the availability of green materials and resources.

\section{Method}

To fulfil the technical requirements of green building as stated in GBCI's rating system, the DED is analysed by using the following specific documents: (1) owner project requirement, (2) architectural drawings, (3) architectural specification, (4) structural performance design 
and report, (5) mechanical and electrical specifications, (6) fire prevention plan and design, (7) façade and interior designs, (8) landscape design, (9) energy modelling and simulation results, and (10) tenant or user's guidelines. By using Green Building Rating Tool for New Building Version 1.2, all required documents from DED will be analysed from the following criteria and parameters:

- Appropriate site development (ASD), which includes: basic green area, site selection, community accessibility, public transportation, bicycle, site landscaping, micro climate, and storm water management

- Energy efficiency and conservation (EEC), which includes: electrical submetering, OTTV calculation, energy efficiency measure, natural lighting, ventilation, climate change impact, and on-site renewable energy

- Water conservation (WAC), which includes: water metering, water calculation, water use reduction, water fixtures, water recycling, alternative water resources, rainwater harvesting, and water efficiency landscaping

- Material resource and cycle (MRC), which includes: fundamental refrigerant, building material reuse, environmentally processed products, Non-ODS usage, certified wood product, prefab materials, and regional materials

- Indoor health and comfort (IHC), which includes: outdoor air introduction, $\mathrm{CO}_{2}$ monitoring, environmental tobacco smoke control, chemical pollutants, outside view, visual comfort, thermal comfort, and acoustic level

- Building environmental management (BEM), which includes: basic waste management, green professional as a member of the project team, pollution of construction activity, advanced waste management, proper commissioning, green building data submission, fit out agreement, and occupant survey.

To achieve the targeted greenship level for DR of new building, GBCI's rating system uses the following score: $\geq 56$ for Platinum, 44-55 for Gold, 35-43 for Silver, and 27-34 for Bronze.

\section{Results and Discussion}

\subsection{Appropriate site development (ASD)}

Basic green area and site landscaping are needed to maintain and improve the quality of micro climate, to reduce $\mathrm{CO} 2$ emission and other air pollutants, to prevent soil erosion, to minimize the load of drainage system, and to maintain the balance of clean water and soil water system. The rating system requires vegetation to cover landscape area and free from any building structures and top-soil hardscape. For new construction, the required total green area is at least $10 \%$ of total site area. From DED documents it is observed that basic green area is 10,149 sqm from 33,343 sqm of total site area, or equals with $30.44 \%$. It is also found that $50 \%$ of this green area is covered by various size of plantations and trees.

Site selection aspect is important to prevent larger impact of construction project on the environment, as well as to maintain the sustainability of surrounded ecosystem. From DED documents it is shown that the building site has required city's infrastructures, such as inbound roads, electrical and lighting networks, drainage system, garbage dumping system, fire protection system, pedestrian ways, telephone landlines, and clean water installations.

Community accessibility defines good connectivity with related public facilities around, or at least $300 \mathrm{~m}$ from the site. Public transportation criteria encourage the inhabitants and visitors of the building to use public transportation modes. In UM, the design of pedestrian ways from and to the site are designed to accommodate these needs. As for the use of bicycle, from DED documents it is shown that there will be 98 units of 
bicycle parking facilities to accommodate about 1,944 people using bicycle inside campus area. The targeted scores obtained from ASD components are shown in Table 1.

Table 1. Targeted score for Appropriate Site Development

\begin{tabular}{|c|l|c|}
\hline Code & \multicolumn{1}{|c|}{ Criteria } & $\begin{array}{c}\text { Targeted } \\
\text { score for DR }\end{array}$ \\
\hline ASD-P & Basic green area & P \\
\hline ASD 1 & Site selection & 1 \\
\hline ASD 2 & Community accessibility & 2 \\
\hline ASD 3 & Public transportation & 1 \\
\hline ASD 4 & Bicycle & 1 \\
\hline ASD 5 & Site landscaping & 1 \\
\hline ASD 6 & Micro climate & 2 \\
\hline & \multicolumn{2}{c}{ Sub total } \\
\hline
\end{tabular}

\subsection{Energy efficiency and conservation (EEC)}

Electrical sub-metering is set to control and monitor the use of electricity as a basis for implementing better energy management. Electrical drawings in DED have shown some Kwh meter or power energy meter for AC, pumps, laboratories, and elevators. As for OTTV calculations based on SNI 03-6389-2011 for Energy Conservation of Building Envelope, the thermal values transferred to both buildings are $31.78 \mathrm{~W} / \mathrm{m}^{2}$ and $33.42 \mathrm{~W} / \mathrm{m}^{2}$ respectively. According to the standard, these values are still lower than the permitted thresholds.

By using energy simulation software, the energy use in both buildings will have an efficiency up to $180.55 \mathrm{Kwh} / \mathrm{m}^{2}$.year or $32.58 \%$ from the baseline of $267.81 \mathrm{Kwh} / \mathrm{m}^{2}$.year. It will be achieved by using efficient lighting system ( $73 \%$ from natural lighting), the use of lux sensors, and higher AC's coefficient of performance (CoP). The overall targeted scores for EEC components are displayed on Table 2.

Table 2. Targeted score for Energy Efficiency and Conservation

\begin{tabular}{|c|c|c|}
\hline Code & Criteria & $\begin{array}{c}\text { Targeted } \\
\text { score for } D R\end{array}$ \\
\hline EEC-P1 & Electrical sub-metering & $\mathrm{P}$ \\
\hline EEC-P2 & OTTV calculation & $\mathrm{P}$ \\
\hline EEC 1 & Energy efficiency measure & 11 \\
\hline EEC 2 & Natural lighting & 4 \\
\hline EEC 3 & Ventilation & 1 \\
\hline \multirow[t]{2}{*}{ EEC 4} & Climate change impact & 1 \\
\hline & Sub total & 17 \\
\hline
\end{tabular}

\subsection{Water conservation (WAC)}

From DED documents it is observed that water meters are installed at all clean water system of the buildings, particularly for the outlet of deep well to domestic ground water tank. By using GBCI's spread-sheet calculator, the use of water in both buildings has been reduced to 15.59 litre/person-day, or $31.17 \%$ of total water use baseline. As for installed water fixtures (WF), DED documents (plan and section drawings) have the data that there will be 319 items of WF on each building, or $91 \%$ of total baseline number of projected 
WF. According to technical specification and mechanical drawings of DED, the buildings have rainwater harvesting tank with the capacity of $80 \mathrm{~m}^{3}\left(40 \mathrm{~m}^{3}\right.$ each) or equals to $83 \%$ of total rainwater spilled out from the roofs. The targeted scores for WAC criteria are shown in Table 3.

Table 3. Targeted score for Water Conservation

\begin{tabular}{|c|l|c|}
\hline Code & \multicolumn{1}{|c|}{ Criteria } & $\begin{array}{c}\text { Targeted } \\
\text { score for DR }\end{array}$ \\
\hline WAC-P & Water metering & $\mathrm{P}$ \\
\hline WAC-P2 & Water calculation & $\mathrm{P}$ \\
\hline WAC 1 & Water use reduction & 8 \\
\hline WAC 2 & Water fixtures & 3 \\
\hline WAC 4 & Alternative water resource & 2 \\
\hline WAC 5 & Rainwater harvesting & 2 \\
\hline & \multicolumn{2}{|c|}{ Sub total } \\
\hline
\end{tabular}

\subsection{Material resource and cycle (MRC)}

Fundamental refrigerant is a important aspect to assess, since it will affect high level or atmospheric ozone. Based on the technical specifications on DED, both buildings' AC system are designed not to use chloro-fluoro-carbon (CFC) as refrigerant, nor haloalkane (halon) as fire extinguisher agents. The targeted scores from MRC components are displayed on Table 4.

Table 4. Targeted score for Material Resource and Cycle

\begin{tabular}{|c|ll|c|}
\hline Code & \multicolumn{1}{|c|}{ Criteria } & $\begin{array}{c}\text { Targeted } \\
\text { score for DR }\end{array}$ \\
\hline MRC-P & Fundamental refrigerant & P \\
\hline MRC 3 & Non-ODS usage & 2 \\
\hline & & Sub total & 2 \\
\hline
\end{tabular}

\subsection{Indoor health and comfort (IHC)}

To introduce outdoor air in the buildings, the DED documents follow ASHRAE standard 62.1-2007. The designed natural ventilations provides $4 \%$ of the net inhabitable floor area. These openings also help monitoring the concentration of $\mathrm{CO}_{2}$ in air supply mechanism, which is supported by installed Automatic Volume Damper (AVD) in auditorium and seminar rooms. This AVD will help controlling the $\mathrm{CO}_{2}$ not to exceed more than 1,000 $\mathrm{ppm}$, and installed $1.5 \mathrm{~m}$ from the floor close to return air grills or return air ducts. The freshness of outdoor air is also maintained by promulgating the warning of 'No Smoking' in all building area and no provision of smoking area. Thermal comfort in the buildings is set by stabilizing indoor temperature at $25^{\circ} \mathrm{C}$ and relative humidity at $60 \%$. Table 5 shows the projected scores for IHC components. 
Table 5. Targeted score for Indoor Health and Comfort

\begin{tabular}{|c|l|c|}
\hline Code & \multicolumn{1}{|c|}{ Criteria } & $\begin{array}{c}\text { Targeted } \\
\text { score for DR }\end{array}$ \\
\hline IHC-P & Outdoor air introduction & P \\
\hline IHC 1 & $\mathrm{CO}_{2}$ monitoring & 1 \\
\hline IHC 2 & Environmental tobacco smoke control & 2 \\
\hline IHC 3 & Chemical pollutants & - \\
\hline IHC 4 & Outside view & 1 \\
\hline IHC 5 & Visual comfort & - \\
\hline IHC 6 & Thermal comfort & 1 \\
\hline IHC 7 & Acoustic level & - \\
\hline & \multicolumn{2}{|}{} \\
\hline
\end{tabular}

\section{Conclusion}

Based on the analysis results of DED documents for the potentials of fulfilment of GBCI's greenship rating system, it is conclude that overall targeted score for UM's integrated classroom buildings is 47 . This score equals to Gold level of greenship, which is obtained by the score of 8 from ASD components, 17 from EEC components, 15 from WAC components, 2 from MRC components, and 5 from IHC components. The use GBCI's greenship rating system for certifying green building status of UM's two classroom buildings is recommended since this system is potential for local-national adapted system, applicable for almost all types of building, and supported by current available technology.

Special acknowledgement is conveyed to the Institute of Research and Community Services (LP2M) Universitas Negeri Malang (UM) for managing the university's research fund (PNBP) 2018 as financial source and support for this study, and PT Patroon Arsindo (DED Consultant) Jakarta for providing useful data (working drawings, technical specifications, bill of quantity, design concepts, and simulation/modelling results).

\section{References}

1. L. Abdullah, N. Jumadi, R. Sabu, H. Arshad, F.F.M. Fawzy. Journal Teknologi UTMara, 1 (2015)

2. V. Shabunko, C.M. Lim, S. Mathew. Energy and Buildings, 169, 507-516 (2016)

3. H.A. Rahardjo, D. Dinariana. International Journal of Engineering and Technology, 8(1), 1 (2016)

4. A.P. Gürgün, G. Polat, H.G. Bayhan. 12th International Congress on Advances In Civil Engineering, 21-23 (2016)

5. R.D. Wirahadikusumah, D. Ario. International Journal of Construction Management, 15(2), 126-136 (2015)

6. S. Burroughs. Proceedings of the SEB16 Conference, Dubai (2016)

7. Z. Shari, V. Soebarto. International Journal of Sustainable Tropical Design Research and Practice, 8(1), 1-12 (2015)

8. C. Mediastika, K. Lie (2015). Procedia engineering, 118, 546-553 (2015)

9. N.D. Reztrie, I.H. Lubis, H.E. Kusuma, M.D. Koerniawan, R. Budiarto. Green Energy and Applications (ICGEA), International Conference, 166-170 (2018)

10. D.A.J. Harimu, M.S. Tumanduk. (2018, February). IOP Conference Series: Materials Science and Engineering, 306 (1), 012024 (2018) 
11. R. Sipahutar, I. Bizzy. AIP Conference Proceedings 1903 (1), 030004 (2017)

12. M. Wimala, E. Akmalah, M.R. Sururi (2016). Energy Procedia, 100 (1), 469-474 (2016) 